\title{
MEMOIR OF THE WILLIAM ARCHER FAMILY
}

\author{
By Margaret E. Archer Murray
}

This is the second part of the two-part history of the Archer Family written by Margaret E. Archer Murray at the age of 87. The Annals is publishing this article through the courtesy of the author's grandson, Murray Work of Des Moines. The punctuation, capitalization and spelling used by Mrs. Murray have remained unchanged for publication.

The sketches accompanying this history were done for the Annals by William J. "Bill" Wagner, Iowa architect and artist.

\section{Murray}

Now I will tell you a little some thing of the early life of your own grand Father \& my self to begin with William Murray was born in Fredrick Co. Maryland March 81843 his Father passed away when he was quite small. having his wife with 2 small children one a little girl. She then came to Ohio where her Brothers were living when your grand father was 12 years old an uncle took him \& taugt him the Shoe making trade then in 31 the civil war broke out then in 62 his mother died \& he Inlisted right away being then 16 years of age

Inlisted to serve 3 years or untill war was over co $\mathrm{K}$ 122 Reg of Ohio Infiantry was Discharged in June 1865 was made corporal not a verry high office but one step up for a boy only 19 years old he was in Libby Prison 7 months where northern Soldiers suffered many hardships Libbie was counted 2nd worst prison in the South in the winter of 66 he came to Iowa worked on a farm one summer then came to Primrose \& hired to the shoemaker \& worked for him till Feb 69 


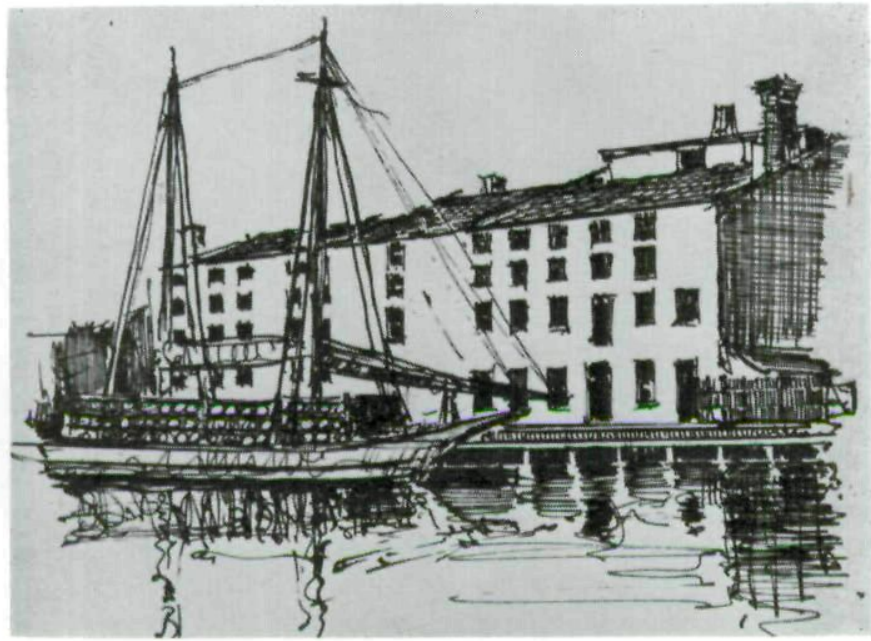

Sketch of Libby Prison

He began coming to our House in June 68 \& on Feb 14 we became Engaged \& on Feb 16 he left Primrose \& went to Milton van Buren Co. \& started in business for him selfe then on October 1469 we were married at the metropolitan Hotel in Ft madison by Presbyerian minister name of W B Nobel was married at $11 \mathrm{a}$ m then after we bought a cook stove \& a few other thing for housekeeping \& had them shiped to Farminglan where we could pick them up later went back home to mothers that was a 20 mile drive Stayed there a week then hired a Farmer with farm wagon to take us \& my few belongings to milton our future Home. distance from Farmington to milton was about 39 miles took us full day to get there that was Oct 21 stayed at his Boarding place till 23 then went to House Keeping 2nd floor in 2 rooms

now Murray I am going to tell you as near as I can just what our Furniture was in our large room had small no 7 cook stove \& that did for heating as well for 2 winters then had a fall leaf table \& 3 chairs a Preforated tin door safe for dishes \& food then turned on Side \& wooden box with calico curtain in front for pots \& pans on top was my work table \& wooden water bucket in that room 
we cooked ate \& sat it had 2 windows \& 3 doors one opened in a Hall one to our bed room \& the other to bed room of our land lady so I dident have much wall space than in our small room had bed Small stand one trunk my trunk was small \& it was pushed under the bed had a mearor which hung above the stand this room had 2 windows, carried our water from a well in back yard \& washed down stairs in land ladies kitchen same day she did they had no children \& they were verry verry good to us in more ways than one the man spoke verry broken French \& she spoke broken Scotch I never know a man that I had more confidence in than good old Frenshman old Presley Marsan

we lived there 17 months in March 71 we Bought an old 4 room House 2 lots with a Barn at Back we lived there 6 years there in that time William Built a double shop out in front on corner one Side he used \& the other rented for Harness Shop

Our first Baby was born there in July \& mother \& Bro J F came to live with us in Nov same year we all lived practly in one room as kitchen was to cold the north Sill had roted \& lift a hole that one could throw a cat out through (maby not quite that big).

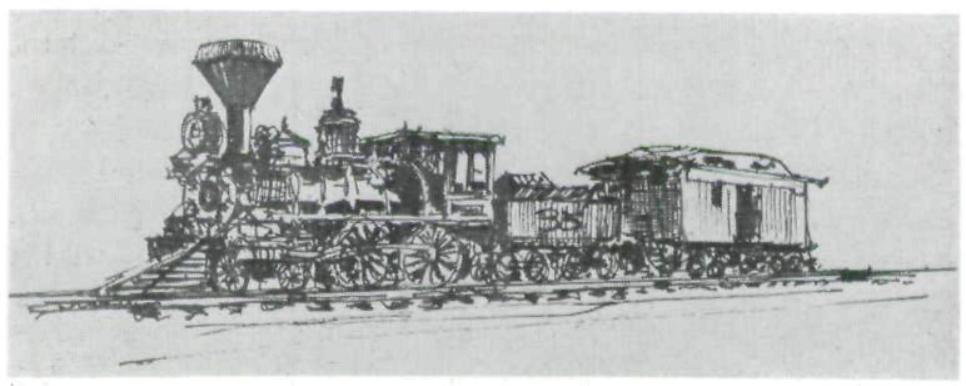

C B \& Q Railroad

Our first Rail Road was built through milton in fall of 72 it was the B C \& Q then later Will moved his Shop Building over in new part of town \& in may 77 he bought a new 6 room House was built in $75 \&$ is still standing we 
got that \& 2 lots for $\$ 600.00$ no improvement at at all but as we got able bought 2 more lots built 2 more Rooms to the House mad some improvement evry year Set out all kinds of fruit till we had at one time the nicest places in milton

when we were married he had only saved $\$ 300.00$ that had to buy tools leather to work with buy what little Furniture we got Pay House rent Shop rent \& our grocery bill we made a rule not to go in debt \& we dident things werent So Expensive at that time but I never had carpets rugs or curtains at my windows till we moved to the new House dident Even have a rocking chair till I was married more than 7 years but most of my neighbors were almost as poor as we were we had no high ups middle class or poor

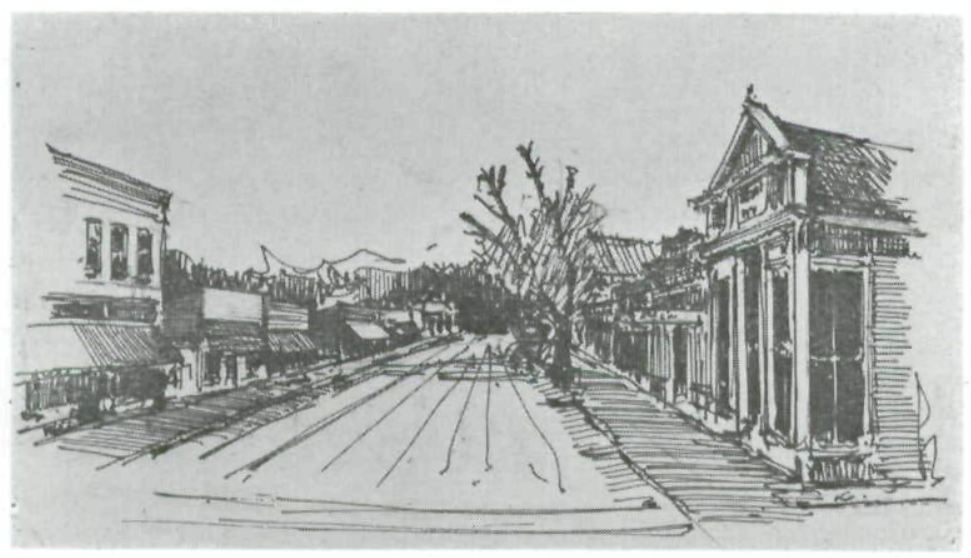

Milton, lowa, about turn of century

Milton only had a Population of about 300 when we first went there after the Rail Road came we soon had a Population of 1300 or more \& now after 50 or 60 years it has a Population of about 900 well we lived there from 1869 to 1919 that is I kept the Property but your grand Father lived there 1915 all that time he Pegged away when I say Pegged I mean that at first he used wooden pegs \& wooden lasts \& used linen thread with hog bristles twisted in the 
end \& sewing awl to make a hole to sew through \& used a pegging awl to make a hole to put in the Pegs how I wish now I had saved some of these old tools to give you

he never took but 2 real vacations the first was in aug 78 he with 4 other men rigged up a coverd wagon \& took a trip out in Kansas took blankets \& slept out at night he sure enjoyed it for a time but got tired of slow travel \& came back by tran \& again in 81 he went to Ohio

when he came Home said he dident enjoy visiting

but he did a lot of hunting when we were first married game was more plentifull wild turkeys quails \& rabbits in winter time wild pidgeons \& Squirls in Sumer time in Summer children went bare foot Shoe work was slack

after years \& years of coaxing the children \& I got him persuaded to apply for a Pension for servis in the war $\$ 12.00$ per month was the amount but was increased till at the time of his Death he was getting $\$ 50.00$ per month if he had lived 6 more years would of gotten 75 when he was about 65 he sold the Shop \& most of the tools \& stock of leather for $\$ 1100$ we that with that \& what we had saved \& the 50 a month he \& I could live verry nicely as both girls were married \& gene was away doing for him self Soldiers were exemped of property tax

then not long after that every thing changed your grand Father passed away in may 1915 \& there I was alone not a relative or child near but a host of Friends.

then what was I going to do well I kept the place 4 years but was there only through the Summer months So I gave it up after living there 45/2 years Some of Happiness Some of Sorrow \& at the last a few of discontent

Here are some of the things your grand dad did enjoy in 92 he joined the masonic franrnity \& I don't think he ever missed many meetings in all the years he lived after that then some years later they oranised a Knights of 
Pythias Lodge in milton and he was a charter membr \& at his Death the masons Knights \& old Soldiers all took part in the Funeral Servise

I left milton in Dec 1915 went to Des moines where both girls lived at that time \& on first of Jan 1916 went to Pensicola Florida Spent 4 months that is a Port for Ships navy yard Fort where Soldiers were stationed Station where there were 8 diferant modles of air plaines made \& tried out daily Old Forts to explore of old Spanish wars \& we could get a ticket at any time to visit Fort Pickens on a government Boat they werent alowed to take pay

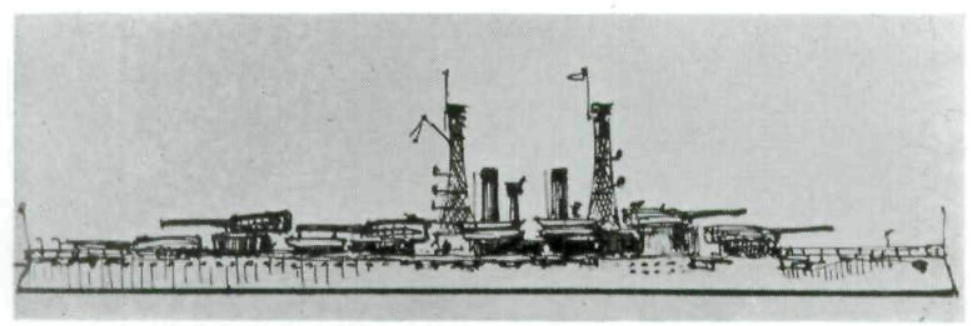

Battleship U.S.S. Pennsylvania

I was all over a Battle Ship it was the Northern Something cant remember just wat. Even let us go in kitchen to see them prepair a meal used great copper vessells to cook in at that time Pensicola had a population of 33000 went a lot of times to Santa Kosa (Rosa) Island on a gasolien launch over there the sand is as white as salt \& so hard in places cant dent it with ones shoe heel The Island is 40 miles long \& the width is from $1 / 2$ mile to $1 \frac{1}{2}$ miles has some trees all along it. Fort Pickens is at the extream Southern end there were only 6 Houses at the Fort those were for married officers who had a Family but hosts of other Buildings for differant uses \& the comisary was a huge place where all the supplyes were kept \& there were a large amount of tents a guide took us through all there was to see except where the Powder was stored that was under ground way back in this was 
in time of world war \& we werent alowed to take a codack (Kodak) with us had to leave it with a Soldier at the entrance \& our Picnic Baskits had to be looked in. The Soldiers were a nice bunch of men \& always seemed to enjoy having us come \& asked us about as many questins as we asked them I spent the day with an Iowa officers wife he asked me if I would only 6 women on the Island \& she was so homesick.

I spent a lovely $3 \frac{1}{2}$ months there then I spent parts of 2 winters in chicago with your Father \& mother in July 1918 I decided to take a trip west went to cody wyoming $\&$ in august went by auto to yelolw stone Park camped out up there a week did our own cooking had taken along 2 tepees to sleep in Snowed just a short $\frac{1}{2}$ hour as we were going throu the golden gate but it soon melted \& we spent a wonderfull week sight seeing went back to cody rested 3 days then Started on another trip to Seattle then up the Sound about 65 miles to arlington wash \& from there 7 miles out in the interior in the mountains where the tall trees grow \& the mountain streems flow.

There Brother J F had a ranch he called it but I called it a little Dairy Farm in a valley between the mts he had a nice little herd of rgisterd cattle at that time he was milking 14 cows \& oh Boy did they have to keep things clean milking Barn milk buckets \& cream Seperater were government inspected Every so often

The Ice Cream Factory at arlington came at 7 a m each dame for the cream he had the water from a mountain Spring piped in his House \& was that water clear \& cold could see the Fish swiming at the Bottom of the stream over the rock bottom he had a pontoon Bridge to cross over to his field \& Fruit of all kinds apples Peaches Prunes \& big black sweet cherries then for Berries Strawberrie Red \& black Raspberries logan berries \& Ever green black berrie could raise almost Evrything in that valley seemed to me the one thing I did not like was the House was $1 / 4$ mile off of the main drag \& never saw a human being pass \& only 3 Ranchs in that valley 


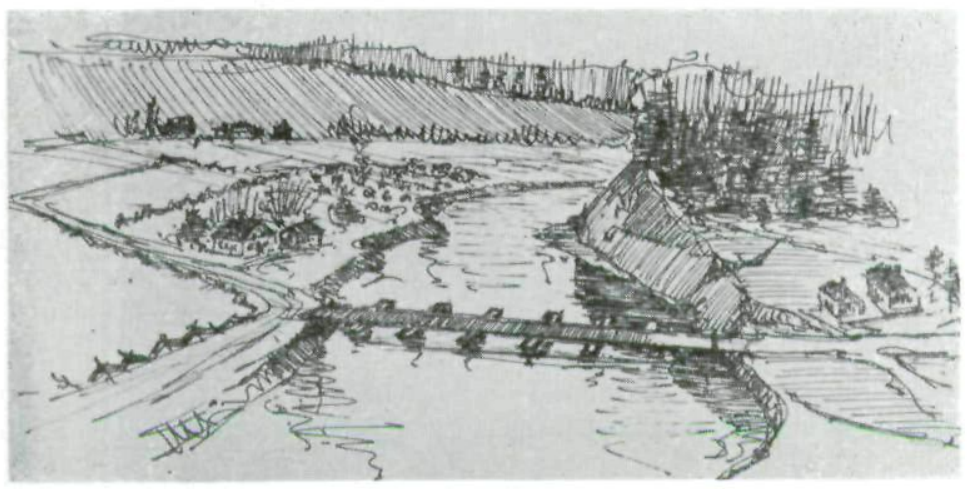

Ranch with Pontoon Bridge over Stream

the timber had been logged in former years the old Skid roads were still there down the $\mathrm{mt}$ side Bro Said one of the big trees would furnish material to build a good sized House

Spent 2 weeks there Spent one week in Seattle with a Friend took boat rides on Lake union \& green Lake had a grand time at both Homes

then left Seattle for Colo Springs where your Folks had moved in the mean time arived there about sept $15 \mathrm{my}$ First Sight of the Dear old Rockies in Colorado

of course I was in the mountains all the time after I got to wyoming I never thought them as imposing \& Beautifull Even the cascades as the Rockies we used to climb \& ramble over in colorado

well to contaninue I stayed with your Folks till 30th of Dec mon at noon \& it had beun to Snow just a little bit \& till we got to goodland it was a Blizard but we kept on going \& got as far as colby Kan the train stalled in a snow drift \& there we stayed 50 long hours \& how the wind howled \& the snow drifted after the Dinamo ran down the lights went out in the cars after that we only had one candle to a coach but all Passengers with Paid tickets got their meals free I was one of that number in our 
car we kept watch meeting new years Eve Sang Songs told Stories \& made Speaches we had one Pullman \& one Dining car on wed night at $10 \mathrm{P} \mathrm{m}$ a Snow Plow reached us with a Freight train behind that \& our train right behind the Freight \& at that we lost 4 hours in reaching Kans City where I was going \& oh was I tired \& dirty for we dident have any hot water on the train to clean up with Wayne lived there at the time So I stayed there till last of Feb then went back to milton Sold my property

Divided all my Bedding Dishes \& any thing the firls wanted then made a sale of all the rest of Furniture \& Every thing loose that Spring of 1919 then I went to Des moines \& on July 9 went again to Colorado Springs where I stayed till. last of June 1920 then went back to D M my next trip I made in november. Same year went to St PetersBurg Floriad on thanksgiving day was gliding down the Tennesee River a Beautifull stream of water reached chattanooga about $4 \mathrm{P} \mathrm{m}$ not far from there is Lookout mountain \& on the side way up toard the top is the word IOWA for somp thing the Iowa Soldiers did in time of civil war from Jacksonville on the East coast we went across to St PetersBurg on the west coast a town at that time of about 1600 mostly all of northerners dident amount to much in summer time Stayed there 5 months while there took a trip to Bradentown Several hours ride on Boat that day 5 of us hired a man with car to take us Sight seeing ene thing was a large grapefruit grove it was one mile Squear 91 trees Each way grapefruit Blossoms arent as large or as Sweet Smelling as orange Blossoms one other place we saw was an old Plantation a great big Stone House \& the negro quarters or cabins which had fallen to ruins \& the big stone building where they worked up the cane into Sugar \& malasses.

then on the last day of march when the wind was high a Friend \& I went by Boat the city of Philadelphia Just a pleasure Boat went to old city of Tampa an old quaint town but I enjoy seeing quaint things \& how I did Enjoy the Boat riding the high waves \& I went almost Every P m 
\& Evening to a Band concert 1/1/2 Blocks from our apartment or stay Home \& hear the musick almost as plain got back to D M on the 16 of april in a big snow storm 1921 my next trip was in June 1923 went to wyoming again last of august went to mont Spent a month on a Ranch oh how I did Enjoy that month out of doors all day in the big open spaces got back to D M that time on the 12 of oct took little trips here \& there till 31 went to calif in aug \& returned last of oct

had a wonderfull time while out there went up on $\mathrm{mt}$ Lowe \& over to catalina Isalnd \& many other Places of intrest to me Especily the ocean in my travels I have been to the atlantic twice \& to the Pacific twice but of all the things I have seen I love the mountains best I think

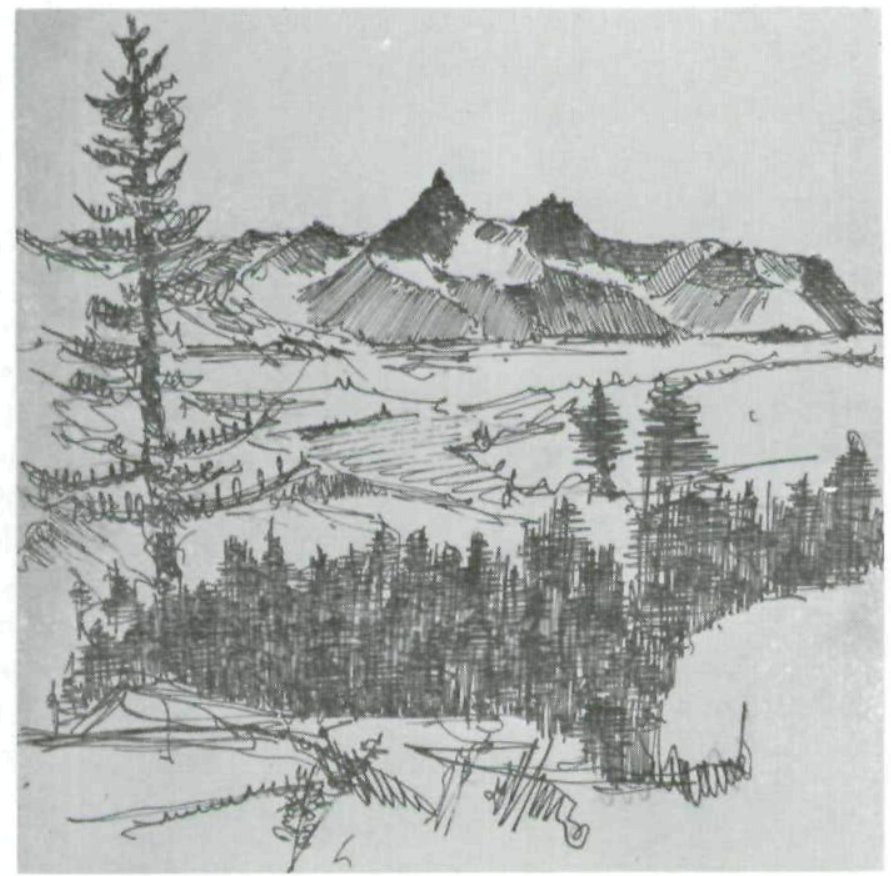

Pilots Peak near Cooke City

of how they have stood in their granduer for ages \& will stand for ages to come well for a couple of years I kind 
of settled down then in aug 34 took a little trip to miniton colo which I Enjoyed imencely \& Since then havent been on a train but take short trips by auto I Snow balled on aug 15 in yellow stone Park \& next on aug 16 snow balled on Pikes Peak

out of the 48 states I have been in 24 of them have been as far East as Evensville Indana \& as far South as St PetersBurg Florida as far west as Southern california \& as far North as northern Iowa

\& now I am gettling old dont know how much good I have done or otherwise but would love to think when I have Passed to the beyond that the world has been better for my having lived in it

$$
\begin{aligned}
& \text { margaret E murray } \\
& \text { June } 28-38
\end{aligned}
$$

I am leaving a lot of space in this Book for your mother to write Some thing of her girlhood days \& after life

Excuse this big mistake I left out one trip I made in 33 Sept 12 I went to St. Joe mo \& spent the Entire winter untill march 4 Except month of Dec Spent that in D M that fall on my 64 wedding day anneversery I went to St Joe mo again for a short stay then on oct 1037 went to Kansas city mo for a months Stay \& came back to D M on the Rocket a new fast I sent this true to nature when one gets old can remember Events 75 years back in their lives but forget things of yesterday this last trip only happened a few months ago any way I am Enjoying Life to the full 
Copyright of Annals of Iowa is the property of State of Iowa, by \& through the State Historical Society of Iowa and its content may not be copied or emailed to multiple sites or posted to a listserv without the copyright holder's express written permission. However, users may print, download, or email articles for individual use. 